\title{
ПОКАЗНИКИ КЛІТИННОГО ЦИКЛУ І ФРАГМЕНТАЦІЇ ДНК-КЛІТИН СЕЛЕЗІНКИ В РАННІ ТЕРМІНИ ПІСЛЯ ТЕРМІЧНОГО ОПІКУ ШКІРИ НА ФОНІ ВВЕДЕННЯ ЛАКТОПРОТЕЇНУ 3 СОРБІТОЛОМ АБО НАЕS-LX-5 \%
}

\begin{abstract}
Резюме. В науковій літературі відсутні дані відносно досліджень особливостей показників клітинного циклу і фррагментації ДНК-клітин селезінки після термічного опіку шкіри на тлі введення інфузійних гіперосмолярних розчинів.

Мета дослідження - встановити особливості показників клітинного циклу і фрагментації ДНК-клітин селезінки через 1; 3 і 7 діб після опікового ушкодження шкіри на тлі введення розчинів лактопротеїну з сорбітолом або HAES-LX-5 \%.

Матеріали і методи. Дослідження виконано на лабораторних білих щурах-самцях масою 155-160 г, отриманих з віварію дУ "Інститут фрармакології та токсикології АМН України". Щурів поділили в експерименті на 6 груп: перша, друга і третя групи щури без термічної травми, яким проводили інфузію 0,9 \% розчину $\mathrm{NaCl}$, лактопротеїну з сорбітолом та HAES-LX-5 \% y дозі 10 мл на кг. У четвертій, п'ятій і шостій групах щурам проводили інфузію 0,9 \% розчину $\mathrm{NaCl}$, лактопротеїну з сорбітолом та HAES-LX-5 \% у дозі 10 мл на кг після опіку шкіри. Опікове ушкодження шкіри викликали шляхом прикладання до попередньо депільованих бічних поверхонь тулуба щурів на 10 с чотирьох мідних пластинок (по дві пластини з кожного боку, кожна з площею поверхні по 13,86 $\mathrm{cm}^{2}$ ), які попередньо упродовж 6 хв нагрівали у воді 3 постійною температурою $100^{\circ} \mathrm{C}$. Гоління бокових поверхонь тулуба щурів, катетеризацію вен, постановку опіків шкіри та декапітацію тварин проводили в умовах внутрішньовенного пропофролового наркозу (із розрахунку 60 мг/кг маси тварини). Вміст ДНК в ядрах клітин селезінки щурів визначали методом проточної цитометрії на багатофрункціональному науково-дослідному проточному цитометрі "Partec PAS" фрірми Partec. Для збудження фллуоресценції DAPI застосовуваль УФ-випромінювання. 3 кожного зразка аналізу нуклеарної суспензії підлягало 20 тис. подій. Циклічний аналіз клітин виконували засобами програмного забезпечення FloMax (Partec, Німеччина) у повній цифровій відповідності згідно з математичною моделлю, де визначали: G0G1 - відсоткове співвідношення клітин фрази G0G1 до всіх клітин клітинного циклу (вміст ДНК = 2c); S - відсоткове співвідношення фази синтезу днК до всіх клітин клітинного циклу (вміст ДНК > 2c та < 4c); G2+M - відсоткове співвідношення фази G2+М до всіх клітин клітинного циклу (ДНК=4C); IP - індекс пролісерації, що визначається за сумою показників S+G2+M; BP - блок пролісерації, який оцінюють за співвідношенням S/(G2+M); SUB-G0G1 - інтервал на ДНК-гістограмах RN1 перед піком G0G1, який вказує на ядра клітин із вмістом ДНК<2с (визначення фрагментації ДНК). Статистичну обробку отриманих результатів проводили у ліцензійному пакеті Statistica 6.1 із застосуванням непараметричних методів оцінки отриманих результатів.

Результати досліджень та їх обговорення. При застосуванні розчину лактопротеїну з сорбітолом через 1 добу після опікового ураження шкіри спостерігаються більші середні значення показника S-фрази (на 39,4 \%, p<0,05), порівняно 3 групою після опіку з корекцією 0,9 \% розчину $\mathrm{NaCl}$, однак вони залишаються значно меншими (на $35,4 \%$, p<0,05) відносно середніх значень даного показника в групі без опікового ушкодження. Також спостерігаються більші значення індексу пролісрерації (на 38,6 \%, p=0,076) в групі "опік + лактопротеїн з сорбітолом" порівняно з групою "опік + 0,9 \% розчин NaCl". В цей же термін спостереження при застосуванні HAES-LX-5 \% на тлі опіку шкіри, порівняно з аналогічними показниками групи "опік + 0,9\% розчин NaCl", суттєво меншими виявились показники фаз G0G1 (на 4,8 \%, p<0,05) та інтервалу SUB-G0G1 (на 34,9 \%, р<0,01) і більшими показники S-сази (на 41,1 \%, р<0,05) та індекс пролісрерації (на $32,7 \%$, p<0,05). При порівнянні показників клітинного циклу клітин селезінки між групами "опік + лактопротеїн з сорбітолом" та "опік + HAES-LX-5 \%" через 1 добу експерименту встановлено лише достовірно $(p<0,05)$ на 30,3 \% менші значення інтервалу SUB-G0G1 при застосуванні HAES-LX-5 \%. Таким чином, вже через 1 добу після опіку шкіри розчином лактопротеїну з сорбітолом більш суттєво впливав на синтетичні процеси, a HAES-LX-5 $\%$ - на процеси як снтезу ДНК, так і апоптозу порівняно із застосуванням 0,9 \% розчину NaCl. Подібна картина за характером впливу даних препаратів на показники клітинного циклу клітин селезінки була і через 3 та 7 діб після опікового ураження шкіри. Зокрема, порівняно з показниками групи "0,9 \% розчину $\mathrm{NaCl}$ без опіку" через 3 доби, на фоні опіку та корекції розчином лактопротеїну з сорбітолом більшими виявились середні значення блока пролісерації, а на тлі корекції розчином HAES-LX-5 \% вищими були середні значення показників фази S і блока проліферації та меншими - інтервалу SUB-G0G1. Через 7 діб після опіку шкіри відмінностей при впливі на показники клітинного циклу клітин селезінки між розчинами лактопротеїну з сорбітолом та HAES-LX-5 \% ми не виявили. Однак в обох цих групах були встановлені більші середні значення показників S-фрази, блока пролісрерації та інтервалу SUB-G0G1 порівняно з середніми значеннями аналогічних показників групи "опік + 0,9\% розчину NaCl". Висновки. Застосування розчинів лактопротеїну з сорбітолом або HAES-LX-5 \% на тлі опікового ушкодження шкіри сприяють більш ефективному процесу оновлення клітин селезінки шляхом стимуляції синтезу днк та меншого рівня апоптозу, особливо при застосуванні HAES-LX-5 \%.
\end{abstract}

Ключові слова: показники клітинного циклу; фрагментація ДНК; селезінка; щури; опік шкіри; розчин лактопротеїну з сорбітолом, розчин HAES-LX-5 \%.

ВСТУП На користь існування можливого захисного механізму клітин селезінки у вигляді гальмування синтетичних процесів і захисту від патологічної стимуляції апоптозу свідчать результати деяких досліджень стосовно порушення поділу клітин селезінки вже з 1 доби після опікового ушкодження шкіри [4]. Також у ряді досліджень $[5,11]$ встановлено різке зниження кількості спленоцитів у перші години після термічного ушкодження шкіри. Дане явище автори пов'язують із різким підвищенням рівня гормонів надниркових залоз, що розвивається у відповідь на опікове ушкодження і потенційно гальмує наступну імунну відповідь [10]. У науковій літературі зустрічаються лише поодинокі публікації, в яких вказується про початок відновлення лімсооїної проліферації, зокрема в селезінці через 48 год після термічного ушкодження шкіри [7].

Однак досліджень особливостей показників клітинного циклу і фррагментації ДНК-клітин селезінки після термічного опіку шкіри на тлі введення інфуззійних гіперосмолярних розчинів ми не виявили.

Метою дослідження було встановлення особливостей показників клітинного циклу і фррагментації ДНК клітин селезінки через 1; 3 і 7 діб після опікового ушкодження 
шкіри на тлі введення розчинів лактопротеїну з сорбітолом або HAES-LX-5 \%.

МАТЕРІАЛИ I МЕТОДИ В рамках наукового співробітництва між Вінницьким національним медичним університетом імені М. І. Пирогова (ВНМУ ім. М. І. Пирогова) і дУ "Інститут патології крові та транссрузійної медицини НАМН України" (м. Львів) та ВНМУ ім. М. І. Пирогова і Національним медичним університетом імені О. О. Богомольця проведено експериментальне дослідження дії контрольного інфрузійного препарату - 0,9 \% розчину $\mathrm{NaCl}$, ресреренс-препарату - розчину лактопротеїну з сорбітолом та досліджуваного препарату - розчину HAES-LX-5 \% (розроблений в ДУ "Інститут патології крові та трансфузійної медицини НАМН України") на структуру селезінки інтактних щурів, а також на ранніх термінах (1; 3 та 7 доби) після опікової травми шкіри.

Дослідження виконано на лабораторних білих щурахсамцях масою 155-160 г, отриманих 3 віварію ду "Інститут фрармакології та токсикології АМН України". Упродовж експерименту всіх тварин утримували в умовах віварію BНМУ ім. М. І. Пирогова (температура в приміщенні - в межах $24-25^{\circ} \mathrm{C}$, вологість повітря - у межах 40-60 \%) на стандартному водно-харчовому раціоні, при вільному доступі до води та їжі. Усі досліди проводили з урахуванням рекомендацій Європейської комісії щодо проведення медико-біологічних досліджень з використанням тварин та медичними рекомендаціями Державного фармакологічного центру МОЗ України та Правил до клінічної оцінки безпеки фрармакологічних засобів (GLP) $[1,3]$ та Правил гуманного ставлення до експериментальних тварин (затверджено Комітетом 3 біоетики ВНМУ ім. М. І. Пирогова - протокол № 1 від 14.01.2010).

Усі розчини вводили у нижню порожнисту вену після її катетеризації в асептичних умовах через стегнову вену в дозі 10 мл/кг маси тіла тварини - середня терапевтична доза, яку розрахували розробники HAES-LX-5 \% відповідно до існуючих рекомендацій [3]. Після кожного введення колоїдно-гіперосмолярних розчинів, просвіт підшитого під шкіру катетера заповнювали титрованим розчином гепарину (0,1 мл гепарину на 10 мл 0,9 \% розчину $\mathrm{NaCl})$. Перше введення колоїдно-гіперосмолярних розчинів (упродовж 5-6 хв) здійснювали через годину після початку експерименту (депіляції бокових поверхонь тулуба і нанесення опіку шкіри), а наступні інфузії - 1 раз на добу протягом перших 7 діб проведення експерименту.

Гоління бокових поверхонь тулуба щурів, катетеризацію вен, постановку опіків шкіри та декапітацію проводили в умовах внутрішньовенного пропофолового наркозу (із розрахунку 60 мг/кг маси тварини).

180 щурів поділили в експерименті на 6 груп: перша, друга і третя - щури без термічної травми, яким проводили інфузію 0,9 \% розчину $\mathrm{NaCl}$, лактопротеїну з сорбітолом та HAES-LX-5 \% у дозі 10 мл на кг. У четвертій, п'ятій і шостій групах щурам проводили інсрузію 0,9% розчину $\mathrm{NaCl}$, лактопротеїну з сорбітолом та HAES-LX-5 $\%$ у дозі 10 мл на кг після опіку шкіри.

Опікове ушкодження шкіри спричиняли шляхом прикладання до попередньо депільованих бічних поверхонь тулуба щурів на 10 с чотирьох мідних пластинок (по дві пластини 3 кожного боку, кожна 3 площею поверхні по $\left.13,86 \mathrm{~cm}^{2}\right)$, які попередньо упродовж 6 хв нагрівали у воді 3 постійною температурою $100 \mathrm{C}^{\circ}[6,9]$. При цьому, згідно $з$ фрормулою M. O. Lee [8], загальна площа ураження поверхні шкіри у щурів складала 21-23 \%. Така площа при даній експозиції є достатньою для формування опіку II-III ступенів (згідно з класифікацією, яку прийнято на XX з'їзді хірургів України, м. Тернопіль, 2000 р.) та викликання шокового стану середнього ступеня тяжкості [2].

Вміст ДНК в ядрах клітин селезінки щурів визначали методом проточної цитометрії. Суспензії ядер із клітин селезінки отримували за допомогою спеціального розчину для дослідження ядерної ДНК CyStain DNA фрірми Partec, Німеччина, відповідно до протоколу-інструкції виробника. Даний розчин дозволяє швидко та одночасно виконувати екстракцію ядер і маркувати ядерну ДНК діамідиносреніліндолом (DAPI), який входить до його складу. В процесі виготовлення нуклеарних суспензій використовували спеціальні одноразові фрільтри CellTrics 50 мкм (Partec, Німеччина). Проточний аналіз виконували на багатофункціональному науково-дослідному проточному цитометрі "Partec PAS" фрірми Partec, Німеччина, в НДЦ ВНМУ ім. М. І. Пирогова.

Для збудження флуоресценції DAPI застосовували УФ-випромінювання. 3 кожного зразка нуклеарної суспензії аналізу підлягало 20 тис. подій. Циклічний аналіз клітин виконували засобами програмного забезпечення FloMax (Partec, Німеччина) у повній цифрровій відповідності згідно з математичною моделлю, де визначали: G0G1 - відсоткове співвідношення клітин фрази G0G1 до всіх клітин клітинного циклу (вміст ДНК=2c); $\mathrm{S}$ - відсоткове співвідношення фрази синтезу ДНК до всіх клітин клітинного циклу (вміст ДНК > 2с та < 4c); G2+M - відсоткове співвідношення фрази G2+M до всіх клітин клітинного циклу (ДНК=4c); IP - індекс проліферації, яку визначають за сумою показників S + G2+M; BP - блок проліферації, який оцінюють по співвідношенню $\mathrm{S} /(\mathrm{G} 2+\mathrm{M})$; SUB-G0G1 - інтервал на ДНК-гістограмах RN1 перед піком G0G1, який вказує на ядра клітин із вмістом ДНК < 2c (визначення фррагментації ДНК).

Статистичну обробку отриманих результатів проводили у ліцензійному пакеті Statistica 6.1 із застосуванням непараметричних методів оцінки отриманих результатів. Оцінювали характер розподілу ознак за кожним із отриманих варіаційних рядів, встановлювали середні значення кожної ознаки, які вивчали, і величини стандартних квадратичних відхилень. Достовірність відмінностей між незалежними кількісними величинами визначали за допомогою U-критерію Манна-Уїтні.

РЕЗУЛЬТАТИ ДОСЛІДЖЕНЬ ТА ЇХ ОБГОВОРЕННЯ При порівнянні середніх значень показників клітинного циклу клітин селезінки щурів на тлі корекції наслідків опіку шкіри різними препаратами в різні терміни спостереження виявлені наступні розбіжності (табл. 1). Через 1 добу експерименту застосування лактопротеїну з сорбітолом для корекції опікового ушкодження, порівняно з показниками групи із застосуванням 0,9 \% розчину $\mathrm{NaCl}$ без опіку, суттєво більшими виявились середні значення показників срази G0G1 $(p<0,05)$ при відсутності достовірної розбіжності $(p=0,076)$ даного показника із показниками групи корекції опіку 0,9 \% розчину $\mathrm{NaCl}$. Подібну динаміку зафріксовано для середніх значень показників фрази G2+M $(p<0,05)$, IP $(p<0,05)$ та інтервалу SUB-G0G1 $(p<0,01)$. Лише для ВР не встановлено достовірних розбіжностей середніх значень між усіма трьома групами порівняння (табл. 1).

Через 1 добу після опіку шкіри на тлі застосування HAES-LX-5 \% порівняно 3 аналогічними показниками групи із застосуванням 0,9 \% розчину $\mathrm{NaCl}$ без опікового ураження зафріксовано суттєву різницю в середніх зна- 
Таблиця 1. Показники клітинного циклу клітин селезінки у щурів через добу після опіку шкіри та застосування 0,9 \% розчину $\mathrm{NaCl}$, розчинів лактопротеїну з сорбітолом або HAES-LX-5 \% (M $\pm \sigma)$

\begin{tabular}{|c|c|c|c|c|c|c|}
\hline \multirow{2}{*}{ Група тварин } & \multicolumn{6}{|c|}{ Показник клітинного циклу } \\
\hline & G0G1 & $\mathrm{S}$ & $\mathrm{G} 2+\mathrm{M}$ & IP & $\mathrm{BP}$ & SUB-G0G1 \\
\hline 0,9 \% розчину $\mathrm{NaCl}$ & $74,38 \pm 5,01$ & $5,826 \pm 1,095$ & $19,79 \pm 4,27$ & $25,62 \pm 5,01$ & $0,302 \pm 0,066$ & $4,876 \pm 1,201$ \\
\hline Опік + 0,9 \% розчину $\mathrm{NaCl}$ & $91,08 \pm 3,01$ & $2,284 \pm 0,753$ & $6,638 \pm 2,308$ & $8,922 \pm 3,007$ & $0,356 \pm 0,077$ & $12,03 \pm 3,27$ \\
\hline Опік + розчин ЛС & $85,34 \pm 5,87$ & $3,766 \pm 0,977$ & $10,77 \pm 5,13$ & $14,54 \pm 6,00$ & $0,372 \pm 0,071$ & $11,24 \pm 2,10$ \\
\hline $\mathrm{p}_{\text {(NaCl- опік ЛC) }}$ & $<0,05$ & $<0,05$ & $<0,05$ & $<0,05$ & $>0,05$ & $<0,01$ \\
\hline $\mathrm{p}_{\text {(опік NaCl-oniк ЛC) }}$ & $=0,076$ & $<0,05$ & $>0,05$ & $=0,076$ & $>0,05$ & $>0,05$ \\
\hline Опік + розчину HAES & $86,74 \pm 3,05$ & $3,878 \pm 0,836$ & $9,384 \pm 2,322$ & $13,26 \pm 3,05$ & $0,418 \pm 0,050$ & $7,830 \pm 1,258$ \\
\hline$p_{\text {(NaCl- опік HAES) }}$ & $<0,01$ & $<0,05$ & $<0,01$ & $<0,01$ & $<0,05$ & $<0,05$ \\
\hline $\mathrm{p}_{\text {(onik NaCl- onik HAES) }}$ & $<0,05$ & $<0,05$ & $>0,05$ & $<0,05$ & $>0,05$ & $<0,01$ \\
\hline $\mathrm{p}_{\text {(опік ЛC - опік HAES) }}$ & $>0,05$ & $>0,05$ & $>0,05$ & $>0,05$ & $>0,05$ & $<0,05$ \\
\hline
\end{tabular}

ченнях усіх показників фрази G0G1 ( $<<0,01)$, S-фрази $(p<0,05), G 2+M(p<0,01)$, IP $(p<0,01)$, BP $(p<0,05)$ та інтервалу SUB-G0G1 $(p<0,05)$ (табл. 1$)$. Також встановлено різницю між показниками середніх значень G0G1 (p<0,05), S-срази $(p<0,05)$, IP $(p<0,05)$ та SUB-G0G1 $(p<0,01)$ із показниками групи корекції опіку 0,9% розчину $\mathrm{NaCl}$. Єдиний показник, що має розбіжність через 1 добу після опікового ураження на фроні корекції лактопротеїном з сорбітолом та HAES-LX-5 \%, є середнє значення інтервалу SUBG0G1 ( $<<0,05)$. На нашу думку, це свідчить про більш виразний вплив саме розчину HAES-LX-5 \% на гальмування патологічного апоптозу, спричиненого опіковим ушкодженням шкіри.

При порівнянні показників клітинного циклу клітин селезінки у щурів через 3 доби після опіку шкіри та застосуванні 0,9\% розчину $\mathrm{NaCl}$, розчинів лактопротеїну з сорбітолом або HAES-LX-5 \% за даними проточної ДНК-цитометрії також встановлено суттєві розбіжності (табл. 2).

Показники клітинного циклу клітин селезінки через 3 доби після опікового ушкодження та корекції лактопротеїном з сорбітолом порівняно з групою "0,9\% розчину $\mathrm{NaCl}$ без опіку шкіри" суттєво відрізняються лише за рахунок більших значень ВP $(p<0,01)$ та фррагментації ДНK SUBG0G1 ( $<<0,01)$, що може відзеркалювати недостатній вплив даного препарату на гальмування патологічного апоптозу. Однак середні значення показника ВР на тлі застосування лактопротеїну з сорбітолом $€$ значно меншими $(p<0,05)$ від аналогічного показника групи "корекції опіку 0,9 \% розчину $\mathrm{NaCl}$ (табл. 2).

Через 3 доби після опікового ушкодження і корекції розчином HAES-LX-5 \%, порівняно із показниками групи "0,9 \% розчину $\mathrm{NaCl}$ без опіку шкіри”, відмічають суттєво більші середні значення показника S-срази $(p<0,01)$, BP $(p<0,01)$ та інтервалу SUB-G0G1 $(p<0,01)$. Можемо припустити, що в даний термін експерименту препарат більш виразно сприяв оновленню клітинної популяції шляхом стимуляції синтезу ДНК на тлі посиленого апоптозу. Порівняно з показниками групи "опік $+0,9 \%$ розчину $\mathrm{NaCl}$ всі середні значення показників клітинного циклу мали достовірні відмінності ( $p<0,05-0,01)$, окрім ВР, що вказує на більш суттєвий вплив розчину HAES-LX-5 \% на клітинний цикл клітин селезінки порівняно 3 даним розчином. Про більш виражений вплив на синтез саме HAES-LX-5 $\%$, порівняно із лактопротеїном із сорбітолом, вказує той факт, що через 3 доби лише середні значення показника S-срази виявились достовірно більшими $(p<0,05)$ саме на тлі застосування HAES-LX-5 \% (табл. 2).

Через 7 діб після опіку шкіри на тлі застосування розчину лактопротеїну з сорбітолом, порівняно $з$ аналогічними показниками групи при введенні 0,9\% розчину $\mathrm{NaCl}$ без опікового ушкодження, встановлено, що середнє значення показника фази G0G1 $€$ меншим $(p<0,05)$, a ceредні значення показників S-срази, IP, ВP та інтервалу SUB-G0G1 - більші $(p<0,05-0,01)$ (табл. 3). Тобто через 7 діб компенсаторно посилюється синтез ДНК із одночасним збереженням підвищеного рівня апоптозу. Про це також опосередковано свідчить і відмінність лише середніх значень показників орази $\mathrm{G} 2+\mathrm{M}(\mathrm{p}<0,05)$ та інтервалу SUBG0G1 $(p<0,01)$ із аналогічними середніми значеннями показників групи "опік + 0,9 \% розчину $\mathrm{NaCl}$ " (табл. 3).

Середні значення показників групи опік із корекцією розчином HAES-LX-5 \% через 7 діб мають відмінності з тотожними середніми значеннями показників групи із введенням $0,9 \%$ розчину $\mathrm{NaCl}$ без опіку у вигляді більших значень

Таблиця 2. Показники клітинного циклу клітин селезінки у щурів через 3 доби після опіку шкіри та застосування 0,9 \% розчину $\mathrm{NaCl}$, розчинів лактопротеїну з сорбітолом або HAES-LX-5 \% (M $\pm \sigma)$

\begin{tabular}{|c|c|c|c|c|c|c|}
\hline \multirow{2}{*}{ Група тварин } & \multicolumn{6}{|c|}{ Показник клітинного циклу } \\
\hline & G0G1 & $\mathrm{S}$ & $\mathrm{G} 2+\mathrm{M}$ & IP & $\mathrm{BP}$ & SUB-G0G1 \\
\hline 0,9 \% розчину $\mathrm{NaCl}$ & $74,74 \pm 5,34$ & $5,690 \pm 1,193$ & $19,57 \pm 4,35$ & $25,26 \pm 5,34$ & $0,290 \pm 0,035$ & $5,166 \pm 1,374$ \\
\hline Опік + 0,9 \% розчину $\mathrm{NaCl}$ & $85,49 \pm 3,21$ & $5,866 \pm 1,606$ & $8,646 \pm 2,305$ & $14,51 \pm 3,20$ & $0,718 \pm 0,294$ & $19,38 \pm 2,24$ \\
\hline Опік + розчину ЛС & $79,55 \pm 8,48$ & $6,210 \pm 2,235$ & $14,24 \pm 6,29$ & $20,45 \pm 8,48$ & $0,462 \pm 0,101$ & $13,74 \pm 4,56$ \\
\hline $\mathrm{p}_{\text {(NaCl- опік ЛC) }}$ & $>0,05$ & $>0,05$ & $>0,05$ & $>0,05$ & $<0,01$ & $<0,01$ \\
\hline $\mathrm{p}_{\text {(опік NaCl- опік ЛC) }}$ & $>0,05$ & $>0,05$ & $>0,05$ & $>0,05$ & $<0,05$ & $=0,076$ \\
\hline Опік + розчину HAES & $71,41 \pm 4,97$ & $9,480 \pm 2,618$ & $19,83 \pm 1,07$ & $29,31 \pm 3,57$ & $0,476 \pm 0,111$ & $9,396 \pm 1,651$ \\
\hline$p_{\text {(NaCl- onik HAES) }}$ & $>0,05$ & $<0,05$ & $>0,05$ & $>0,05$ & $<0,01$ & $<0,01$ \\
\hline $\mathrm{p}_{\text {(опiк NaCl- onik HAES) }}$ & $<0,01$ & $<0,05$ & $<0,01$ & $<0,01$ & $=0,076$ & $<0,01$ \\
\hline $\mathrm{p}_{\text {(опік ЛC - опік HAES) }}$ & $>0,05$ & $<0,05$ & $>0,05$ & $>0,05$ & $>0,05$ & $=0,076$ \\
\hline
\end{tabular}


ISSN 1681-276Х. ВІСНИК НАУКОВИХ ДОСЛІДЖЕНЬ. 2018. № 1

Таблиця 3. Показники клітинного циклу клітин селезінки у щурів через 7 діб після опіку шкіри та застосування 0,9 \%

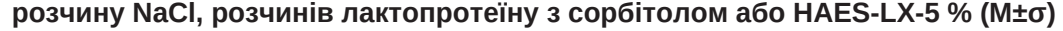

\begin{tabular}{|c|c|c|c|c|c|c|}
\hline \multirow{2}{*}{ Група тварин } & \multicolumn{6}{|c|}{ Показник клітинного циклу } \\
\hline & G0G1 & $\mathrm{S}$ & $\mathrm{G} 2+\mathrm{M}$ & IP & BP & SUB-G0G1 \\
\hline 0,9 \% розчину $\mathrm{NaCl}$ & $72,45 \pm 3,52$ & $5,484 \pm 1,215$ & $22,06 \pm 2,98$ & $27,55 \pm 3,53$ & $0,252 \pm 0,054$ & $4,850 \pm 1,860$ \\
\hline Опік + 0,9 \% розчину $\mathrm{NaCl}$ & $69,74 \pm 2,96$ & $13,17 \pm 2,17$ & $17,09 \pm 1,45$ & $30,26 \pm 2,96$ & $0,774 \pm 0,122$ & $13,18 \pm 3,34$ \\
\hline Опік + розчин ЛС & $66,84 \pm 3,17$ & $12,69 \pm 2,63$ & $20,47 \pm 1,53$ & $33,16 \pm 3,17$ & $0,622 \pm 0,137$ & $7,270 \pm 0,815$ \\
\hline $\mathrm{p}_{\text {(NaCl- опік ЛC) }}$ & $<0,05$ & $<0,01$ & $>0,05$ & $<0,05$ & $<0,01$ & $<0,05$ \\
\hline $\mathrm{p}_{\text {(опік NaCl- опік ЛC) }}$ & $>0,05$ & $>0,05$ & $<0,05$ & $>0,05$ & $>0,05$ & $<0,01$ \\
\hline Опік + розчин HAES & $70,89 \pm 3,66$ & $9,498 \pm 1,268$ & $19,60 \pm 2,83$ & $29,10 \pm 3,66$ & $0,490 \pm 0,070$ & $6,952 \pm 0,804$ \\
\hline $\mathrm{p}_{\text {(NaCl- onik HAES) }}$ & $>0,05$ & $<0,01$ & $>0,05$ & $>0,05$ & $<0,01$ & $<0,05$ \\
\hline $\mathrm{p}_{\text {(onik NaCl- onik HAES) }}$ & $>0,05$ & $<0,05$ & $>0,05$ & $>0,05$ & $<0,01$ & $<0,01$ \\
\hline $\mathrm{p}_{\text {(опік ЛC - опік HAES) }}$ & $=0,076$ & $>0,05$ & $>0,05$ & $=0,076$ & $>0,05$ & $>0,05$ \\
\hline
\end{tabular}

показників S-срази ( $p<0,01)$, BP $(p<0,01)$ та інтервалу SUBG0G1 (p<0,05) (табл. 3). Аналогічні відмінності зафріксовано з середніми значеннями показників групи корекції опікового ураження 0,9 \% розчину $\mathrm{NaCl}$ (табл. 3). Вказані відмінності дозволяють припустити, що на тлі корекції розчином HAESLX-5 \% зберігається компенсація ушкодження шляхом підвищеного синтезу ДНК та рівня апоптозу. Однак відмінностей при впливі на показники клітинного циклу клітин селезінки розчинів лактопротеїну з сорбітолом та HAESLX-5 \% через 7 діб після опіку шкіри ми не зафіксували $(p>0,05)$ (табл. 3). На наш погляд, це свідчить про однаковий вплив досліджуваних препаратів на параметри клітинного циклу саме в цей термін дослідження.

Таким чином, при застосуванні розчинів лактопротеїну 3 сорбітолом або HAES-LX-5 \% встановлені відмінності показників клітинного циклу клітин селезінки вже через 1 добу після опіку шкіри, порівняно із тваринами після опіку шкіри та застосуванням 0,9\% розчину $\mathrm{NaCl}$. Так, при використанні лактопротеїну з сорбітолом спостерігаються більші середні значення показника S-фрази (на 39,4 \%, $p<0,05)$, порівняно з середніми значеннями показників групи після опіку з корекцією 0,9 \% розчину $\mathrm{NaCl}$, однак вони залишаються значно меншими (на $35,4 \%, p<0,05$ ) відносно середніх значень даного показника в групі без опікового ушкодження. Всі інші середні значення показників клітинного циклу не мають достовірних розбіжностей між групами "опік + лактопротеїн з сорбітолом" та "опік + 0,9 \% розчину $\mathrm{NaCl}$ " через 1 добу спостереження. Однак спостерігаються більші значення індексу проліферації (на $38,6 \%, p=0,076$ ) в групі "опік + лактопротеїн з сорбітолом" порівняно з "опік + 0,9 \% розчину NaCl" через 1 добу спостереження. В цей же термін спостереження при застосуванні HAES-LX-5 \% на тлі опіку шкіри, порівняно з аналогічними показниками групи "опік + 0,9\% розчину $\mathrm{NaCl}$ ", суттєво меншими виявились показники фраз G0G1 (на 4,8 $\%$, p<0,05) та інтервалу SUB-G0G1 (на 34,9\%, p<0,01) i більшими показники S-срази (на $41,1 \%$, р<0,05) та індекс проліферації (на 32,7 \%, p<0,05). Відмітимо, що більшість середніх значень показників клітинного циклу клітин селезінки в даній групі суттєво не відрізнялись від середніх значень показників групи "опік + лактопротеїн з сорбітолом", за винятком середнього значення показника інтервалу SUB-G0G1, який виявився достовірно $(p<0,05)$ на 30,3 $\%$ меншим порівняно із аналогічним показником групи "опік + лактопротеїн з сорбітолом". Можемо зазначити, що вже через 1 добу експерименту ми встановили відмінності у впливі розчинів HAES-LX-5 \% та лактопротеїн з сорбітолом на показники клітинного циклу клітин селезінки на тлі опі- кового ушкодження шкіри порівняно з застосуванням 0,9 $\%$ розчину $\mathrm{NaCl}$, а саме, лактопротеїн з сорбітолом більш суттєво впливав на синтетичні процеси, a HAES-LX-5 \% - на процеси як снтезу ДНК, так і апоптозу.

Подібна картина за характером впливу даних препаратів на показники клітинного циклу клітин селезінки була і через 3 та 7 діб після опікового ураження шкіри. Зокрема, порівняно з показниками групи 0,9 \% розчину $\mathrm{NaCl}$ без опіку через 3 доби, на тлі опіку та корекції розчином лактопротеїн з сорбітолом більшими виявились середні значення блока проліферації, а на тлі корекції розчином HAES-LX-5 \% більшими стали середні значення показників фрази S і блока проліферації та меншими - інтервалу SUB-G0G1. Відмітимо, що лише на тлі HAESLX-5 \% середні значення показників S-срази виявились суттєво більшими в даний термін відносно аналогічного показника груп "опік + 0,9 \% розчину $\mathrm{NaCl}$ " та "опік + лактопротеїн з сорбітолом". На наш погляд, це свідчить, що в даний термін експерименту розчин HAES-LX-5 \% більш виразно сприяв оновленню клітинної популяції шляхом стимуляції синтезу ДНК на тлі збереження посиленого апоптозу на тлі опікового ушкодження.

Через 7 діб після опіку шкіри відмінностей при впливі на показники клітинного циклу клітин селезінки між розчинами лактопротеїну з сорбітолом та HAES-LX-5 \% ми не виявили. Однак в обох цих групах були встановлені більші середні значення показників S-фрази, блока пролісрерації та інтервалу SUB-G0G1 порівняно з середніми значеннями аналогічних показників групи "опік + 0,9 \% розчину $\mathrm{NaCl}$.

Отже, ми встановили, що розчини лактопротеїн 3 сорбітолом та HAES-LX-5 \% справляють позитивний вплив на показники клітинного циклу клітин селезінки після опікового ушкодження шкіри у вигляді сприяння оновленню клітинної популяції шляхом стимуляції синтезу ДНК та меншого рівня апоптотичного ушкодження. Саме розчину HAES-LX-5 \% притаманний більш виражений вплив на гальмування апоптозу порівняно з корекцією лактопротеїном з сорбітолом.

ВИСНОВКИ Застосування розчинів лактопротеїну 3 сорбітолом або HAES-LX-5 \% на тлі опікового ушкодження шкіри сприяють більш ефективному процесу оновлення клітин селезінки шляхом стимуляції синтезу ДНК та меншого рівня апоптозу, особливо при застосуванні HAES-LX-5 \%.

Перспективи подальших досліджень полягають у клінічній апробації розчинів лактопротеїну з сорбітолом та HAES-LX-5 \% при термічних опіках шкіри. 


\section{СПИСОК ЛІТЕРАТУРИ}

1. Науково-практичні рекомендації з утримання лабораторних тварин та роботи з ними / [Ю. М. Кожем'якін, О. С. Хромов, Н. У. Болдирєва та ін.]. - К. : Інтерсервіс, 2017. - 182 с.

2. Ожоговый шок: оптимизация интенсивной терапии / В. К. Гусак, В. П. Шано, Ю. В. Заяц [и др.] // Український медичний часопис. - 2002. - № 5, Т. 31. - С. 84-88.

3. Стесранов О. В. Доклінічні дослідження лікарських засобів : метод. реком. / О. В. Стефанов. - К. : Авіцена, 2001. - 528 с.

4. Effects of ethyl pyruvate on cell-mediated immune function in rats with delayed resuscitation after burn injury / Y. Q. Dong, Y. M. Yao, P. Wei [et al.] // Zhongguo Wei Zhong Bing Ji Jiu Yi Xue. - 2005. - Vol. 17, No. 1. - P. 12-15.

5. Fazal N. Burn-injury affects gut-associated lymphoid tissues derived CD4+ T cells / N. Fazal, A. Shelip, A. J. Alzahrani // Results in Immunology. - 2013. - No. 3. - P. 85-94.

6. Gunas I. Method of thermal burn trauma correction by means of cryoinfluence / I. Gunas, I. Dovgan, O. Masur // Abstracts are presented in zusammen mit der Polish Anatomical Society with the participation of the Association des Anatomistes Verhandlungen der
Anatomischen Gesellschaft, Olsztyn (p. 105). Jena - München : Der Urban \& Fischer Verlag, 1997.

7. Impairment of splenic B and T lymphocytes in the early period after severe thermal injury: immunohistochemical and electron microscopic analysis / T. Maekawa, H. Kajihara, K. Okabayashi [et al.] // Burns. - 2002. - No. 28. - P. 329-339.

8. Lee M. O. Determination of the surface area of the white rat with its application to the expression of metabolic results / M. O. Lee // Am. J. Physiol. - 1989. - No. 24. - P. 1223.

9. Regas F. C. Elucidating the vascular response to burns with a new rat model / F. C. Regas, H. P. Ehrlich // J. Trauma. - 1992. Vol. 32, No. 5. - P. 557-563.

10. Schwacha M. G. The cellular basis of post-burn immunosuppression: macrophages and mediators / M. G. Schwacha, I. H. Chaudry // Int. J. Mol. Med. - 2002. - Vol. 10, No. 3. P. 239-243.

11. Simvastatin reduces burn injury-induced splenic apoptosis via downregulation of the TNF- $\alpha /$ NF-KB pathway / G. Zhao, Y. M. Yu, M. Kaneki [et al.] // Ann. Surg. - 2015. - Vol. 261, No. 5. - P. 1006-1012.

Отримано 02.01.18

\author{
(CN. P. Ocheretna ${ }^{1}$, Yu. I. Guminskiy ${ }^{1}$, I. V. Gunas ${ }^{2}$ \\ M. Pyrohov Vinnytsia National Medical University ${ }^{1}$ \\ International Academy of Integrative Anthropology ${ }^{2}$
}

\title{
INDICATORS OF CELL CYCLE AND DNA FRAGMENTATION OF SPLEEN CELLS IN EARLY TERMS AFTER THERMAL BURNS OF SKIN ON THE BACKGROUND OF USING "LACTOPROTEIN WITH SORBITOL" OR HAES-LX-5 \%
}

Summary. In the scientific literature, there is no research data relative performance characteristics of the cell cycle and DNA fragmentation spleen cells after thermal skin burn on the background of the introduction of hyperosmolar infusion solutions.

The aim of the study - is to establish the characteristics of the cell cycle and fragmentation of the cells of the spleen after 1,3 and 7 days after burn injuries of the skin with the introduction of solutions of "lactoprotein with sorbitol" or HAES-LX-5\%.

Materials and Metohods. The research was carried out on laboratory white rats males weighing 155-160 g, obtained from the vivarium of the Institute of Pharmacology and Toxicology of the Academy of Medical Sciences of Ukraine. The rats were divided into 6 groups in the experiment: 1,2 and 3 groups - rats without thermal trauma, which were infused with $0.9 \% \mathrm{NaCl}$ solution, "lactoprotein with sorbitol" and HAES-LX-5\% in dose $10 \mathrm{ml}$ per $\mathrm{kg}$. In the 4, 5 and 6 groups $0.9 \% \mathrm{NaCl}$ solution, "lactoprotein with sorbitol" and HAES-LX-5\% in a dose of $10 \mathrm{ml}$ per $\mathrm{kg}$ after skin burning were administered to the rats. Burn skin damage was caused by applying to the pre-depilated lateral surfaces of the trunk of the rats for 10 seconds four copper plates (two plates on each side, each with a surface area of $13.86 \mathrm{~cm}^{2}$ ) which were preheated for 6 minutes in constant temperature water $100^{\circ} \mathrm{C}$. Shaving of the lateral surfaces of the trunk of the rat, catheterization of the veins, staining of skin burns and decapitation of the animals was carried out under conditions of intravenous propofol anesthesia (at the rate of $60 \mathrm{mg} / \mathrm{kg}$ of animal weight). The DNA content of the rat spleen cell nuclei was determined by flow cytometry at the Partec multifunctional flow cytometer "Partec PAS". UV radiation was used to stimulate DAPI fluorescence. From each sample of the nucleic suspension of the analysis subject to 20 thousand events. Cellular analysis of the cells was carried out using FloMax software (Partec, Germany) in full numeric matching according to the mathematical model, which determined: G0G1 - percentage ratio of G0G1 phase cells to all cells of the cell cycle (DNA content $=2 \mathrm{c}$ ); $\mathrm{S}-$ percentage ratio of the phase of DNA synthesis to all cells of the cell cycle (DNA content $>2 \mathrm{c}$ and $<4 \mathrm{c}$ ); $\mathrm{G} 2+\mathrm{M}$ - percentage ratio of the $\mathrm{G} 2+\mathrm{M}$ phase to all cells of the cell cycle (DNA = 4c); IP - the index of proliferation, which is determined by the sum of the indices $S+G 2+M$; $B P-$ block of proliferation, which is evaluated by the ratio $S$ / $(G 2+M)$; SUB-GOG1 is an interval on the DNA histograms RN1 before the peak GOG1, which indicates the cell nuclei containing DNA $<2 c$ (DNA fragmentation detection). The statistical processing of the obtained results was carried out in the licensed package "Statistica 6.1" with the use of nonparametric methods for evaluating the results.

Results and Discussion. In the application of the solution of "lactoprotein with sorbitol", after 1 day after burn skin damage, bigger mean values of the S-phase $(39.4 \%, \mathrm{p}<0.05)$ were observed in comparison with the burn group after correction by $0.9 \% \mathrm{NaCl}$ solution, however, they remain significantly lower (by $35.4 \%, p<0.05$ ) relative to the mean values of this indicator in groups without burn injury. Also, higher values of the index of proliferation $(38.6 \%, p=0.076)$ in the burn group + "lactoprotein with sorbitol" compared with the burn group $+0.9 \% \mathrm{NaCl}$ solution were observed. At the same time, when using HAES-LX-5\% against the background of skin burns, compared with similar indicators of the burn group $+0.9 \% \mathrm{NaCl}$ solution, the indexes of the G0G1 phases were significantly lower (by $4.8 \%$, $p<0.05$ ) and the interval of SUB-G0G1 (by $34.9 \%, p<0.01$ ) and higher S-phases (by $41.1 \%, p<0.05$ ) and the proliferation index (by $32.7 \%, p<0.05$ ). When comparing the cell cycle parameters of the spleen cells between the groups of burn + "lactoprotein with sorbitol" and burn + HAES-LX-5\%, after 1 day of the experiment, only a significant $(p<0.05)$ by $30.3 \%$ lower values of the SUB- G0G1 established when applied with HAES-LX-5\%. Thus, after 1 day after burning the skin, "lactoprotein with sorbitol" had a more significant effect on synthetic processes, and HAES-LX-5\% - on processes both DNA synthesis and apoptosis compared with the use of $0.9 \% \mathrm{NaCl}$ solution. A similar picture of the nature of the effect of these drugs on the cell cycle parameters of the spleen cells was observed after 3 and 7 days after the burn injury of the skin. In particular, in comparison with the indicators of $0.9 \% \mathrm{NaCl}$ solution without burn after 3 days, on the background of burn and correction with the drug "lactoprotein with sorbitol" the average values of the proliferation block were higher, and on the background of correction with HAES-LX-5\% higher become the average values of the parameters of phase S and the block of proliferation and smaller - interval SUB-G0G1. It should be noted that only on the background of HAES-LX-5\% average values of the 
phase S indicators were significantly higher at the given time relative to the same indicator of burn groups $+0.9 \% \mathrm{NaCl}$ solution and burn + "lactoprotein with sorbitol". This indicates that at the time of the experiment HAES-LX-5\% more clearly contributed to the renewal of the cell population by stimulating DNA synthesis against the background of enhanced apoptosis in the background of burn injury. After 7 days after skin burn, there were no differences in the effect on the parameters of the cell cycle of the spleen cells between the drugs "lactoprotein with sorbitol" and HAES-LX-5\%. However, in both of these groups, higher mean values of the S-phase, the proliferation block and SUB-G0G1 intervals were found to be higher than the average values of similar burn group parameters $+0.9 \% \mathrm{NaCl}$ solution. Conclusions. The use of "lactoprotein with sorbitol" or HAES-LX-5 \% solutions on the background of burn infections of the skin contributes to a more effective process for the renewal of the spleen cells by stimulating the synthesis of DNA and lower apoptosis level, especially with the use of HAES-LX-5\%.

Key words: cell cycle indexes; DNA fragmentation; spleen; rats; skin burns; lactoprotein with sorbitol; HAES-LX-5 \%.

()Н. П. Очеретная ${ }^{1}$ Ю. И. Гуминский ${ }^{1}$, И. В. Гунас ${ }^{2}$

Винницкий национальный медицинский университет имени Н. И. Пирогова ${ }^{1}$ Международная академия интегративной антропологии, г. Винница ${ }^{2}$

\section{ПОКАЗАТЕЛИ КЛЕТОЧНОГО ЦИКЛА И ФРАГМЕНТАЦИИ ДНК-КЛЕТОК СЕЛЕЗЕНКИ В РАННИЕ СРОКИ ПОСЛЕ} ТЕРМИЧЕСКОГО ОЖОГА КОЖИ НА ФОНЕ ВВЕДЕНИЯ ЛАКТОПРОТЕИНА С СОРБИТОЛОМ ИЛИ НАЕS-LX-5 \%

Резюме. В научной литературе отсутствуют данные относительно исследований особенностей показателей клеточного цикла и фрагментации ДНК-клеток селезенки после термического ожога кожи на фроне введения иноузионных гиперосмолярных растворов. Цель исследования - установить особенности показателей клеточного цикла и фрагментации ДНК клеток селезенки через 1; 3 и 7 суток после ожогового повреждения кожи на фроне введения растворов лактопротеина с copбитолом или HAES-LX-5 \%. Материалы и методы. Исследования выполнены на лабораторных белых крысах-самцах массой 155-160 г, полученных из вивария ГУ “Институт фрармакологии и токсикологии АМН Украины”. Крыс распределили в эксперименте на 6 групп: первая, вторая и третья - крысы без термической травмы, которым проводили инфузию 0,9\% раствора NaCl, лактопротеина с сорбитолом и HAES-LX-5 \% в дозе 10 мл на кг. В четвёртой, пятой и шестой группах крысам проводили инфрузию 0,9 \% раствора NаСІ, лактопротеина с сорбитолом и HAES-LX-5 \% в дозе 10 мл на кг после ожога кожи. Ожоговое повреждение кожи вызвали путем приложения к предварительно выбритым боковым поверхностям туловища крыс на 10 с четырех медных пластинок (по две пластины с каждой стороны, каждая с площадью поверхности по 13,86 см²), которые предварительно в течение 6 м нагревали в воде с постоянной температурой $100^{\circ} \mathrm{C}$. Бритье боковых поверхностей туловища крыс, катетеризацию вен, постановку ожогов кожи и декапитацию животных проводили в условиях внутривенного пропосролового наркоза (из расчета 60 мг/кг массы животного). Содержание ДНК в ядрах клеток селезенки крыс определялось методом проточной цитометрии на многофункциональном научно-исследовательском проточном цитометре "Partec PAS" фрирмы Partec. Для возбуждения фрлуоресценции DAPI применялось УФ-излучение. С каждого образца нуклеарной суспензии анализу подлежало 20 тыс. событий. Циклический анализ клеток выполнялся средствами программного обеспечения FloMax (Partec, Германия) в полном цифровом соответствии согласно математической модели, где определялись: G0G1 - процентное соотношение клеток фазы G0G1 ко всем клеткам клеточного цикла (содержание ДНК = 2c); S - процентное соотношение фразы синтеза ДНК ко всем клеткам клеточного цикла (содержание ДНК > 2c и < 4c); G2 + M - процентное соотношение фразы G2 + М ко всем клеткам клеточного цикла (ДНК = 4c); IP - индекс пролиферации, что определяется по сумме показателей S + G2 + M; BP - блок пролиферации, который оценивается по соотношению S / (G2 + M); SUB-G0G1 - интервал на ДНК-гистограммах RN1 перед пиком G0G1, указывающий на ядра клеток с содержанием ДНК < 2с (определение фрагментации ДНК). Статистическую обработку полученных результатов проводили в лицензионном пакете Statistica 6.1 с применением непараметрических методов оценки полученных результатов.

Результаты исследований и их обсуждение. При применении раствора лактопротеина с сорбитолом через 1 сутки после ожогового поражения кожи наблюдаются большие средние значения показателя S-сразы (на 39,4 \%, p<0,05), по сравнению с группой после ожога с коррекцией 0,9\% раствора $\mathrm{NaCl}$, однако они остаются значительно меньше (на 35,4 \%, р<0,05) относительно средних значений данного показателя в группе без ожогового повреждения. Также наблюдаются большие значения индекса пролисерации (на 38,6 \%, p=0,076) в группе "ожог + лактопротеин с сорбитолом" по сравнению с группой ожог + 0,9 \% раствора NaCl". В этот же срок наблюдения при применении HAES-LX-5 \% на фроне ожога кожи по сравнению с аналогичными показателями группы "ожог + 0,9\% раствора NaCl", существенно меньшими оказались показатели фраз G0G1 (на 4,8 \%, р <0,05) и интервала SUB-G0G1 (на 34,9 \%, р<0,01) и большими показатели S-сразы (на 41,1 \%, p<0,05) и индекс пролиферации (на 32,7 \%, p<0,05). При сравнении показателей клеточного цикла клеток селезенки между группами "ожог + лактопротеин с сорбитолом" и "ожог + HAES-LX-5 \%" через 1 сутки эксперимента установлено только достоверно (р<0,05) на 30,3 \% меньшие значения интервала SUB- G0G1 при применении HAES-LX-5 \%. Таким образом, уже через 1 сутки после ожога кожи лактопротеином с сорбитолом более существенно влиял на синтетические процесCы, a HAES-LX-5 \% - на процессы как синтеза ДНК, так и апоптоза по сравнению с применением 0,9 \% раствора NaСl. Подобная картина по характеру воздействия данных препаратов на показатели клеточного цикла клеток селезенки была и через 3 и 7 суток после ожогового поражения кожи. В частности, по сравнению с показателями группы "0,9 \% раствора $\mathrm{NaCl}$ без ожога" через 3 суток, на фроне ожога и коррекции раствором лактопротеина с сорбитолом большими оказались средние значения блока пролисрерации, а на фроне коррекции раствором HAES-LX-5 \% большими стали средние значения показателей S-сразы и блока пролиферации и меньшими - интервала SUB-G0G1. Через 7 суток после ожога кожи различий во влиянии на показатели клеточного цикла клеток селезенки между растворами лактопротеина с сорбитолом и HAES-LX-5 \% мы не обнаружили. Однако в обоих этих группах были установлены большие средние значения показателей S-фразы, блока пролиферации и интервала SUB-GoG1 по сравнению со средними значениями аналогичных показателей группы "ожог + 0,9 \% раствора $\mathrm{NaCl}$.

Выводы. Применение растворов лактопротеина с сорбитолом или HAES-LX-5 \% на фоне ожогового повреждения кожи способствуют более эффрективному процессу обновления клеток селезенки путем стимуляции синтеза ДНК и меньшего уровня апоптоза, особенно при применении HAES-LX-5 \%.

Ключевые слова: показатели клеточного цикла; фрагментация ДНК; селезенка; крысы; ожог кожи; раствор лактопротеина с сорбитолом; раствор HAES-LX-5 \%. 